\title{
INVESTIGATING CAREER PROGRESSION EXPERIENCES OF WOMEN INTO TOP MANAGEMENT AT A SOUTH AFRICAN BANK
}

\author{
Judy Kobus-Olawale ${ }^{1}$ \\ judy.kobusolawale@gmail.com \\ Chris Schachtebeck ${ }^{1}$ \\ cschachtebeck@uj.ac.za \\ Nelesh Dhanpat \\ Department of Industrial Psychology and People Management ${ }^{2}$ \\ neleshd@uj.ac.za \\ ${ }^{1}$ Department of Business Management ${ }^{2}$ \\ ${ }^{2}$ College of Business and Economics \\ University of Johannesburg \\ PO Box 524, Auckland Park, South Africa, 2006
}

\begin{abstract}
Despite South Africa's progressive and comprehensive labour legislation that promotes gender equality in the workplace, this goal has not been fully achieved as yet. This is particularly evident when comparing managerial ranks, particularly in top management at South African banks. This phenomenon is still present today despite overwhelming evidence, supporting the benefits of a diverse management team. This study, therefore, explores the factors, influencing the underrepresentation of women in top management. Therefore, the main objective was to determine the challenges women face in progressing into top management at a South African bank. The study used a qualitative research approach in the form of a case study at one of the largest South African banks. The population for the study included women in top and senior management of the case study bank. Fifteen semi-structured interviews were conducted. Data were analysed through Atlast T. I. Findings indicate that poor career progression prospects exist, mainly hampered by organisational structure, lack of sponsorship and a hostile working environment. The study adds to the existing body of knowledge by providing insights into barriers to women's progression in the financial services sector and providing practical implementation measures to promote career progression for women.
\end{abstract}

Keywords: career progression, women, banking, South Africa, career advancement, top management, management, employment equity, gender representation, women representation.

DOI: $10.21303 / 2504-5571.2021 .001778$

\section{Introduction}

South Africa's history, marred by periods of segregation along racial lines, discrimination along gender lines was also rampant, particularly for women, and women of colour, who were systematically excluded from meaningfully participating in the economy [1]. Since the start of democracy in 1994, the government has made concerted efforts to repeal legislation that encouraged discrimination and introduced legislation that promotes equality in the workplace [2]. These laws include the Labour Relations Act of 1995, Employment Equity Act, No. 55 of 1998, and the Basic Conditions of Employment Act, No 75. of 1997 [1-3]. The Employment Equity Act (EEA) promotes equity in the workplace and has resulted in more women meaningfully participating in the labour force $[3,4]$. The EEA provides for the implementation of affirmative action measures to ensure that individuals from designated groups are provided with opportunities to promote equitable representation in all occupational levels and categories in an organisation. According to the EEA, women have included the definition of designated groups [5]. Despite the implementation of progressive legislation, women continue to face gender inequality in the workplace, mainly by being less likely to secure employment, 
receiving remuneration lower than men, as well as being less likely to secure employment in managerial and executive positions $[1,4,6]$. While women made up $50.5 \%$ of the working-age population in South Africa in 2020, women are less represented in the workplace and account for $45.2 \%$ of the total employee labour force [7]. When analysed further, at higher occupational levels, such as at the top management level, women account for only $24.4 \%$ of top managers and $35.5 \%$ senior managers. Fajardo (2017) [8] further states that $31 \%$ of South African organisations have no female representation in senior management roles. A similar picture emerges in the South African banking sector. Therefore, the purpose of this study is to explore the reasons for the under-representation of women in the banking sector by focusing on one of the four largest banks in South Africa, also referred to as the Big Four.

This study explores reasons for the under-representation of women in the banking sector, adopting a case study approach. To this end, the literature around gender representation in the South African Banking sector and factors, affecting women's career progression, is discussed next.

\section{1. Gender representation in the South African banking sector}

As a sub-sector of the financial services industry, the South African banking sector is regarded as one of the country's largest employers, with almost 2.5 million employees [9]. The banking sector comprises of financial services providers, such as micro-lenders, credit unions and banks [10]. The importance of the sector for the South African economy cannot be understated, contributing an estimated $21 \%$ to Gross Domestic Product (GDP) [11]. The Big Four are comprised of Standard Bank Limited, Absa Group Limited, FirstRand Limited and Nedbank Limited, employing an estimated $67 \%$ of the banking sector's workforce in 2018 [10]. Over $77 \%$ of the South African adult population relies on banks' financial services, with more than 100 million monthly transactions and ZAR5 trillion worth of assets under management. The market structure can be regarded as an oligopoly, with the Big Four controlling $82 \%$ of the assets in the sector [12]. The Big Four have made substantial progress in improving more equitable gender representation in the workplace, with approximately $60 \%$ of the employees in these organisations comprising of women, which is well above the level in the overall South African labour force at 45.2 \% [9, 10, 13-16]. While these figures at face-value appear promising, a dramatically different picture emerges when analysing female representation at the top management level, with around $30 \%$ of top management comprising women.

\section{2. Factors affecting career progression of women}

Authors such as Rath, Mohanty and Pradhan [17] suggest that the literature on women's career progression can be categorised into two different streams: the institutional or agency approach and equality difference approach. The institutional approach views career progression as a factor of the organisational structure, while the agency approach takes the individual perspective into account, notwithstanding any institutional bottlenecks [17]. The equality approach acknowledges differences between genders and argues that men and women must be differently [17]. Some authors also view women's career progression through three lenses, individual attributes, organisational factors and family responsibilities [18]. Individual traits include skills, personality attributes, years of experience and work ethic [19, 20]. Other critical individual traits for career progression include ambition, emotional intelligence, self-confidence, self-efficacy, extroversion, conscientiousness, social skills and being powerdriven $[6,18,20-22]$. Organisational factors, which have shown to play an essential role in the career progression of women, include the creation of a working environment that enables (i) care work through repositioning of organisational attitudes and provision of support; (ii) personal career growth through career planning, mentoring and challenging work assignments; (iii) organisational work, achieved through transparent performance appraisal systems and flexible working arrangements; (iv) an organisational culture that is supportive of career growth and personal ambitions $[17,23]$. In terms of internal organisational dynamics, gender 
discrimination has been found to have the most significant adverse effect on women's career progression, with networking having the most significant and consistent positive effect [18]. In addition, mentorship and sponsorship increased the probability of career progression of women into top management in financial services [24-26].

\section{3. Theories and Models on Women Representation in Leadership}

While some studies have not found differences in women's leadership effectiveness than men, the under-representation of women in top leadership positions remains a concern [27, 28]. This is reflected in the substantial growth in publications in leadership and gender, with almost 3000 publications in the past 40 years, and the majority emanating after 2010 [29]. Table 1 summarises the theories and models of women representation in leadership and provides a brief overview of each.

\section{Table 1}

Summary of Theories/Models on Women Representation in Leadership

\begin{tabular}{|c|c|}
\hline Theory/ Model & Brief description \\
\hline Gender stereotypes & $\begin{array}{l}\text { Most of the theories and models, relating to women in leadership, refer to gender stereotypes, how } \\
\text { these stereotypes affect how women are treated in the workplace and how women in roles that go } \\
\text { against gender stereotypes behave and feel. }\end{array}$ \\
\hline Glass ceiling effect & $\begin{array}{l}\text { Defined as the blockages and hindrances that women face as they are looking to progress into lead- } \\
\text { ership positions in their organisations [30]. }\end{array}$ \\
\hline $\begin{array}{l}\text { Gender stereotypes and } \\
\text { lack-of-fit model }\end{array}$ & $\begin{array}{l}\text { Purports that women, looking to progress into roles and jobs that are perceived not to fit with the } \\
\text { gender stereotypes, typically associated with women, are subjected to bias, and this bias prevents } \\
\text { these women from being appointed into such roles and jobs [31]. }\end{array}$ \\
\hline Role congruity theory & $\begin{array}{l}\text { Purports that society has descriptive and prescriptive gender role expectations concerning the } \\
\text { types of work that women and men should perform based on gender [32]. }\end{array}$ \\
\hline Stereotype content model & $\begin{array}{c}\text { Argues that stereotypes can be classified and categorised and based on this classification. People } \\
\text { can be perceived as belonging to either the in- or outgroups. Women leaders are perceived as being } \\
\text { in the outgroup and are subjected to active prejudice [33]. }\end{array}$ \\
\hline Stereotype threat & $\begin{array}{c}\text { Describes how members of a negatively stereotyped group are adversely impacted when the nega- } \\
\text { tive stereotype is invoked [34]. }\end{array}$ \\
\hline Queen bee phenomenon & It is related to how the stereotype threat affects women in leadership [35]. \\
\hline
\end{tabular}

\section{4. Research aim}

Few studies have explored the progression of women into top management in the South African private sector context and, particularly, the banking sector, which is the focus of this study. This study aims to fill this void by exploring women's career progression into top management positions in a South African bank from the perspective of women who are already top managers and senior managers.

\section{Method}

A qualitative research method was employed. Although women leadership has been researched considerably in academic literature, there is a shortage of literature on this phenomenon in the South African banking context. This study explored how women leaders in a banking environment perceived and interpreted their career progression, and therefore, a subjectivism ontology was adopted. The epistemological paradigm adopted is that of interpretivism. Interpretivism is defined by Aram and Salipante [36] as a paradigm based on the ontological view that reality is not constant and is instead created by individuals as they experience it. This study is a case study, with the case organisation being one of the big four banks in South Africa. A single case organisation was selected by virtue of being typical and indicative of other industry cases [37]. 
The population comprised of women leaders who are part of the top and senior management of the Bank. The study employed a purposive sampling approach to select the sample to facilitate the research objectives' achievement best. Given that the population size for the subgroup of the research population already part of top management was small (at fewer than 20), it was feasible to collect data from the entire population. Although the total research population of 36 women in the top and senior management were invited to participate, 15 individuals responded and agreed to be interviewed through semi-structured interviews, nine with women in top management and six with women in senior management. The majority of participants (14 of 15) held a postgraduate qualification at Honours and Masters level, with one participant holding an undergraduate degree. Six participants were at their current job level for more than 10 years, four participants between 5-10 years and the remaining five participants between 1-5 years. Data, generated from the interviews, were recorded and transcribed. The collected data were first analysed using a word cloud. Further detailed analysis of the data collected was performed through thematic analysis using ATLAS.ti 8.3.0 software. Ethical clearance for the study was obtained under ethical clearance code 2020BM95, and the study followed ethical principles by ensuring confidentiality, anonymity, right of non-participation and withdrawal.

\section{Results and discussion}

Firstly, the result of the word cloud analysis is presented below in Fig. 1.

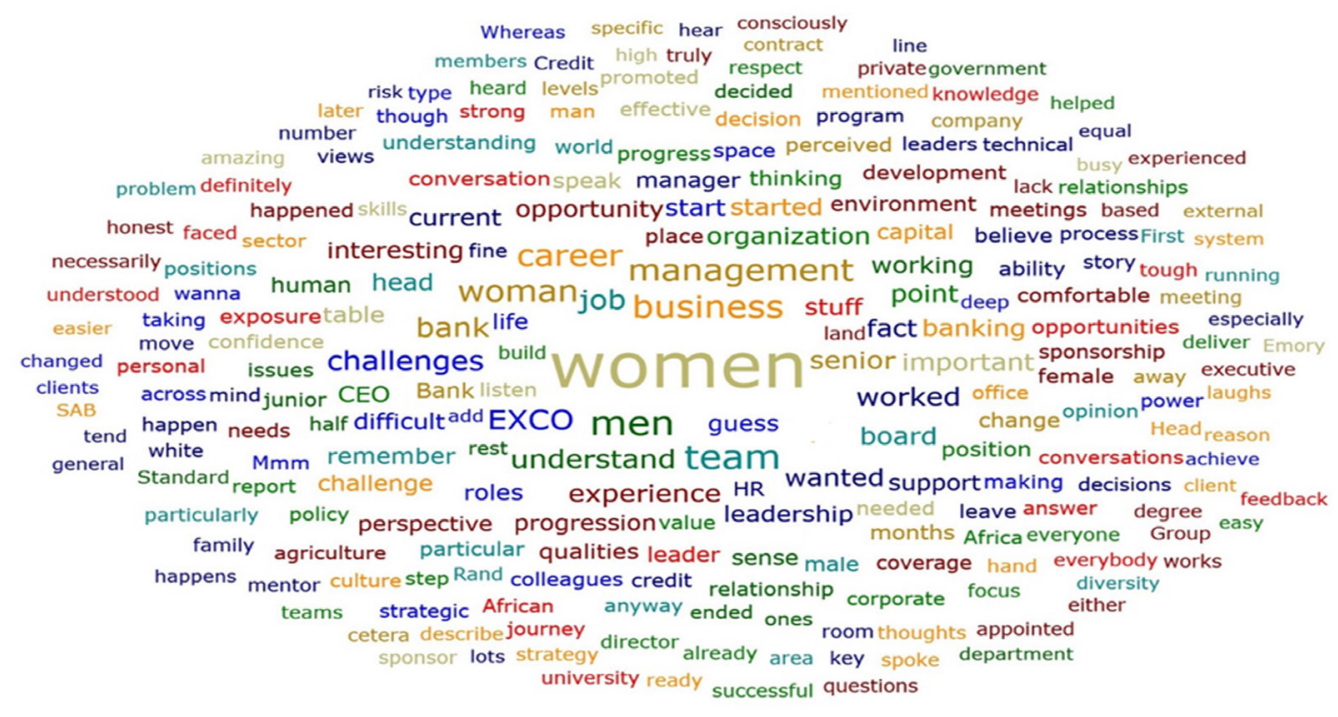

Fig. 1. Word Cloud of Total Transcripts

Dominant words that emerged from the interviews included the terms "women", "exco" (executive committee), "men", "progression", "leadership", “management" and "bank", which are to be expected given the focus of the study. Other words, such as "difficult", "challenges", "sponsorship", "opportunity" and "tough", also emerged. Words that could identify the Bank and the respondents were removed from the word cloud as anonymity was guaranteed. Next, ATLAS.ti 8.3.0 was used to code the transcripts and to develop consolidated codes and networks. The word cloud was used to link research objectives to the empirical data. Following a coding process, five overarching themes emerged around the issue of career progression, which included (1) state of career progression; (2) experience - prejudicial and hostile working environment; (3) experience - challenges with support structure dynamics; (4) experience - career progression from opportunities; and (5) characteristics and qualities for effective career progression. Fig. 2 presents the overall themes, emerged from the study. 


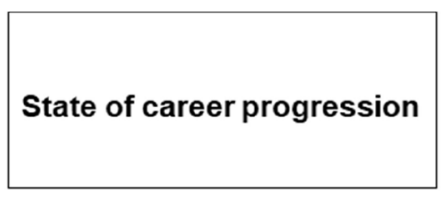

- Low progression

- Transformation in progress

\section{Experience-Prejudicial and hostile environment}

- Gender stereotype

- Queen Bee syndrome

- Favouritism and bias

- Hostile working environment

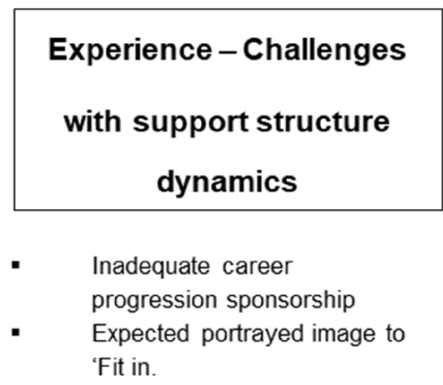

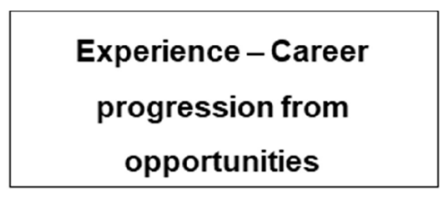

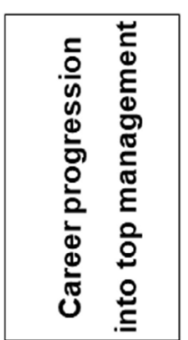

- Importance of being self-driven

- Importance of Building networks and 'Raising hand'

\section{Characteristics and qualities for effective career progression}

- Good people skills

- Know your strengths and weaknesses

- Self-development

- $\quad$ Agile mindset

- Listening skills

- Decision making

- Emotional intelligence

- Ability to network

- Authentic

Fig. 2. Thematic map presenting the five themes and subthemes

\section{Theme 1: State of career progression}

This theme presents the state of career progression of the women to top management positions in the Bank. The respondents viewed the underrepresentation of women at top management as reflective of the poor state of career progression. Many of the respondents who were part of top management further viewed the slow progress of appointing more women into top management to indicate the poor state of career progression, with respondent 4 stating "So, I was the only [one], I mean on all three accounts, I was the only woman, youngest by a country-mile and the only soft skilled practitioner so that was hard". Despite these challenges, it was acknowledged, that improvements in progression had been made and an aim for an overall balance in gender representation had been set. Rath et al. [17] explained that women devote less time and effort to developing their skills and know-how, required to advance in their career, according to human capital and resource theory. However, Parker, Hewitt, Witheriff and Cooper [38] share a different view -that women's career progression is architecturally hampered due to inequity as a result of culture and dynamics, relating to power.

The findings reveal that the respondents perceived a slow progression of women into top management in the Bank. The slow progression was despite the Bank's seeming to have enough "pipeline for progression". This strong pipeline is further evidenced by the top four South African banks, having improved female representation in their organisations to approximately $60 \%[10,13-16]$, which is significantly higher than the average women representation in the South African labour force at $45.2 \%$ [9].

\section{Theme 2: Experience - prejudicial and hostile working environment}

This theme relates to women's experience during their career progression. It was evident, that the respondents perceived that they faced with a prejudicial and sometimes hostile working environment. Five sub-themes were identified, namely, i) gender stereotypes, ii) the existence of queen bee syndrome, iii) favouritism, iv) bias on career progression and v) hostile working envi- 
ronment. In terms of gender stereotypes, the participants indicated that how women were assessed for a possible opportunity in the Bank differed from how men were assessed. It was the expectation for women candidates to be considered more knowledgeable and competent. These findings are congruent with other studies on gender stereotypes, explaining the underrepresentation of women in top leadership [39-41].

In terms of the existence of Queen Bee Syndrome, the participants described this phenomenon as being characterised by some of the women in top management, treating their female subordinate worse than male top managers did. In explaining the queen bee phenomenon, Derks et al. [35] stated that it is grounded on the stereotype threat model that affects women in leadership. From the literature, the queen bee phenomenon or syndrome is a term, given to individual women who seek to be successful in male-dominated careers by distancing themselves from other women while adopting a more agentic style [35]. The most prevailing aspect of queen bee syndrome in the case, as articulated by the respondents, was women in top management physically detaching from other women in lower positions; this then served to support and validate the existing gender hierarchy. The queen bee syndrome typically results in subordinates being resistant to women leaders and the women leaders themselves not being liked in organisations, which further impedes women's progression into more senior positions [42].

In terms of Favouritism and Bias in Career Progression, the respondents felt that the Bank had organisational politics and significantly influenced who became part of the top management team. According to nine respondents, five of whom were in senior management, advancing into top management does not seem to depend on how one performs but rather on the person's being known and liked. The respondents also believed that perceived bias in top management was also a challenge because there was no consistency in the process and system of how one progressed into leadership roles. Some roles were dependent on whether the candidate had a good relationship with senior leaders. The lack-of-fit model states that due to leaders' stereotypical attributes being at odds with the gender stereotypes, associated with women, women, seeking to be leaders, are subjected to bias [42]. The stereotype content model goes further by outlining the types of biases women face when looking to be promoted into leadership. It purports that career women, as a result of being in jobs that are perceived as male roles, are subject to hostile sexism [43].

It was evident from the participants' perceptions, that there were possibilities of conflicts between the co-workers due to misunderstandings, a difference in views on ideas and poor communication, which were summed up as a hostile working environment. The empirical research shows that when women face challenges $[44,45]$, hostility may arise. This hostility took the form of some of the respondents' having conflict with colleagues at the same level or a level above in senior manager respondents. Of the 15 participants interviewed, seven indicated experiencing ongoing conflict in the workplace. These findings are aligned with the literature, with the lack-of-fit model, the stereotype content model and the associated BIAS map, purporting that women in leadership experience biases. The respondents perceived that there was also sexism. According to Offerman et al. [18], gender discrimination has a significant negative impact on women's career progression more than any other factors.

Theme 3: Experience - Challenges with Support Structure Dynamics

Findings indicated that some individuals were influential and willing to support people they believed in and became their career sponsor. Eight of the nine respondents in top management mentioned that they had career sponsors who positively influenced their career progression into top management. These career sponsors, in all cases, were male. The respondents stated that they regarded themselves as fortunate to have sponsors and mentors within the workplace to give them guidance and direction. There were no well-developed or formalised mentoring and sponsorship programme, designed deliberately to advance women's careers. Overall, all of the respondents identified sponsorship as a key requirement for career progression in the Bank. Although the respondents indicated that they were sponsored and mentored during their progression process, some respondents believed that the industry still lacked sponsorship channels for the upcoming leaders. There was also a view that men were more comfortable, sponsoring other men as opposed to 
women, with Respondent 11 stating "Men sponsor other men a lot easier than they would sponsor a woman". The majority (eight out of nine) of the respondents in top management had sponsors and mentors who were instrumental in their promotion. The findings are aligned with Cirincione-Ulezi [26], Hill and Wheat [25] and Atkinson [24], who found that mentorship and sponsorship increase the likelihood of women progressing into top management.

Further, according to the respondents, sometimes the Bank's protocols required a person to change who they are to portray a particular image to get to top management. The participants' perceptions in senior management (five out of six) were that women get noticed and fit in (or are considered fit in) if they change. These changes included changes to dress code. The participants thought that making these changes improved the probability of their being considered for top management positions. This pressure to fit in appears to be felt more by women in senior management, looking to progress into top management, than women already in top management. This is congruent with the lack-of-fit model, which purports that because of gender stereotypes, associated with women, they are viewed as the wrong "fit" for leadership roles [27]. The lack-of-fit model further claims that when making promotion decisions, this perceived lack of fit results in women's being, perceived as not possessing the attributes that are required to be successful in top management [27, 31].

\section{Theme 4: Experience - Career Progression From Opportunities}

Some of the respondents highlighted some positive experiences about growth, learning to better themselves, maintaining good relationships, and building credibility. The importance of being self-driven emerged as a critical theme. The participants indicated that as the individual progresses to a leadership role, there must be room to learn to be better through their experience. This is regarded as critical as there is always room for improvement, and this led to the individual women's having a better understanding of themselves and becoming better versions of themselves. Some of the respondents indicated that they had self-developed to get to the top positions. According to Pradhan, Jena and Panigrahy [46], being self-driven entails going above and beyond the stated work requirements and responsibilities.

A further sub-theme that emerged was the Importance of Building Networks and 'Raising Hand', as most of the respondents regarded building a good reputation as essential as one progresses to a higher level. It was highlighted, that they needed to move out of their comfort zones, learn new things, and build good relationships for the women to succeed. The respondents believed that strong relationships made it easy to trust colleagues and people in authority within the Bank. Respondents in top management indicated that they had experienced good relationships and credibility with the senior executive members who steered their journey as they progressed to leadership roles. These strong relationships with senior executives also helped the participants be confident and learn more about them as leaders. The respondents shared that exposure and proper networking in the workplace are a necessity. Some of the respondents believed that women sometimes are not recognised in the workplace, and even when they are, top leaders still believed they lacked drive. As such, most of the respondents indicated that it was critical to express their ambition to progress and prove their worthiness actively. The findings of this sub-theme are consistent with literature as, according to Offerman et al. [18], networking has the single most important and consistent positive effect on the career progression of women. Burkinshaw and White [47] shared this view and stated that networking is essential to women's career progression; however, due to the prejudices against women who pursue leadership roles, networking can be challenging for women.

Theme 5: Characteristics and Qualities for Effective Career Progression

This theme was developed to understand the characteristics and qualities that women should possess for effective career progression into top management based on the participants' responses. The main characteristics that emerged included i) good people skills; ii) self-awareness; iii) agile mindset; iv) listening skills; v) good decision-making skills; vi) emotional intelligence; vii) ability to network 
In terms of Good People Skills, the participants identified these skills as being critical for effective leadership. The participants viewed this quality as important because, according to them, a leader must be more sensitive and empathise with employees who are facing various challenges at work and in their personal lives. Respondent 2 captured this sentiment by stating "I think that you need to understand that you're working with people and that not all people are the same and what you need to do is that you need to figure the people around you out [sic.] and what makes them tick and you work with that". Lammers and Gast's [48] definition of people skills ties up closely to the Mayer et al. [6] definition of emotional intelligence, which comprises self-regard, self-awareness, social responsibility, interpersonal relationships, empathy, among other factors. Downey et al. [49] also confirmed that leaders with higher emotional intelligence levels tend to adopt a transformational leadership style.

The other attribute that the respondents identified related to self-awareness. The participants believed that it is essential that the leader knows the areas they excel in and how to help develop employees in those areas. They also stated that it is also important, that leaders know their weaknesses so that a leader can also self-reflect and try to improve themselves. The respondents already in top management identified this sub-theme very strongly as key to progressing into top management. Shah and Shah [50] define self-awareness as a component of emotional intelligence. Self-awareness is the ability to identify one's strengths, weaknesses, and emotions and how these affect others [50]. According to Rubens, Schoenfeld, Schaffer, and Leah [51], research supports a positive association between self-awareness and leadership success.

A further sub-theme included an agile mindset, which the respondents defined as being intelligent, having the ability to think quickly and problem-solve. The participants viewed having an agile mindset as essential because it allows a leader to thrive in this ever-changing environment. Xu and $\mathrm{Yu}$ [52] define adaptability as social and psychological skills that a leader has that improve their ability to cope with an uncertain and ever-changing environment. Adaptability is linked to better performance and career satisfaction [52]. Takawira [53] defines adaptability as the psychosocial skills that one has to self-regulate and adapt to succeed in one's career goals.

Additionally, the participants believed that in order for any person to make an informed decision, they needed to have excellent listening skills. The participants stated that leaders frequently deal with the clients; therefore, they must have excellent listening skills to help the clients with their needs. According to Udin, Handayani, Yunaiwan and Rahardja [54] a leader is responsible for directing their team, influencing employees' behaviours and attitudes and motivating them to achieve organisational goals. Effective listening is a significant part of effective business communication [55].

In terms of good decision-making skills, the participants believed that one has to make decisions that will affect the whole team and, frequently, the whole organisation. Most of the respondents believed that all decisions made must always be those that will result in an organisation's best outcomes. This sub-theme came up strongly among the participants already in top management. According to Kanadlı, Torchia and Gabaldon [56], being a minority in boards and executive committees limits women's ability to contribute to board decisions. This is because of the social barriers that women leaders face in the committees and boards, they sit on due to them, being the outgroup, following the stereotype content model [43, 56]. Women leaders, being categorised as an outgroup, are subjected to bias in the form of envious prejudice $[43,57,58]$. As a result, their positive contributions are less likely to be recognised as such, and their inputs are viewed as less valid and trustworthy than their in-group counterparts [56].

A further sub-theme included Emotional Intelligence, the participants stated that emotional intelligence helps a leader know when and when not to use emotions. They viewed emotional intelligence as an important attribute because women, looking to be promoted into top management, face gender stereotypes and biases, and to navigate those barriers, emotional intelligence is required. Emotional intelligence is a key attribute for career progression into top management [6, 49, 57-60]. According to Downey et al. [49], transformational leaders tend to display higher emotional intelligence levels. Darvin, Pegoraro and Berri [61] state that women 
typically have elevated levels of emotional intelligence and empathy than men, which improves women's overall leadership abilities.

The respondents viewed the ability to network as vital because, for any business to grow, the people within that organisation must be flexible and communicate effectively with different people from different levels of life. Also, having a strong network gives women allies who can talk for them even if they are not in the room. Jauhar and Lau [62] found that networking substantially influenced women's career progression, especially into leadership. Networking is vital because it increases employees' visibility in the organisation and higher networking levels are linked to more career opportunities [62]. Women in organisations tend to have more challenges than men in forming and connecting to networks in an organisation [62]. This is because of gender stereotyping, which also result in "old boys' networks" that are exclusionary to women $[62,63]$.

Lastly, authentic leadership skills, the respondents highlighted that a leader must always be authentic. An authentic leader emphasises building legitimacy through a honest and genuine relationship with subordinates. Critically, this relationship is built on ethical values. The respondents highlighted that a leader who is not authentic is not taken seriously, and their leadership style is always questioned, making subordinates lose respect for such leaders and their authority. Respondent 15 summarised this succinctly by stating "Actually, being a good leader is about being authentic". Authentic leadership is defined by Woolley, Caza and Levy [64] as transformational leadership that goes beyond by incorporating ethical and moral considerations. Woolley, Caza and Levy [64] further state that authentic leadership talks to leaders' behaviours, relating to self-awareness, fairness, transparency, ethical and moral behaviour. According to Hopkins and O'Neil [65], authentic leadership is complex for women leaders because: (i) gender stereotypes as women who behave as authentic leaders typically experience backlash; and (ii) organisations are engendered and tend to favour men; therefore, women leaders tend not to bring their most authentic selves to work.

\section{1. Limitations and Recommendations}

The views and opinions of women in top and senior management were collected. The perceptions of men across all job levels and women middle and junior managers were not pursued and could have helped better understand the phenomenon. This study was limited to understanding the phenomenon from the perspective of women in top management and those women who are a level lower in senior management. The generalisability of the study, however, is limited by the respondents' being only from Johannesburg. To improve the generalisability of findings, future studies should seek to replicate this study in different settings, for example, with a larger sample size that spans more South African banks. The generalisability can also be improved by replicating the study with banks from other countries or replicating it in other sectors outside the banking industry. These duplicate studies can then compare the emerging findings and themes to those of this study.

Future research can also seek to broaden the perspective and explore the phenomenon from a male top and senior management perspective by exploring male managers' experiences of women's career progression into top management. As no data were collected from the respondents regarding their family responsibilities, future research can delve deeper into the emerging theme of how family responsibilities impact women's career progression into top management. Another area for future research that can build upon this study is exploring how organisations can effectively mitigate against the various challenges women face when looking to be promoted into top management.

\section{Conclusion}

Although women make up $50.5 \%$ of the working-age population, they only account for $45.2 \%$ of the South African employed labour force [7]. This underrepresentation becomes more marked as one progresses up the occupational levels, with the top management level having only $24.4 \%$ women as top managers. This underrepresentation is despite South Africa's having very comprehensive labour laws that seek to promote gender equality and representation in the workplace [1]. 
Literature has identified many benefits to having a gender diversified top management team, such as, increased profitability, better decision making, improved governance and better corporate responsibility to name a few [27, 66-69]. Therefore, based on this research, organisations need to seek to promote gender representativity and equality at the top management level. Based on this study's findings, the respondents at the Bank had a perception that women experience many challenges when seeking to progress to top management. Some of the challenges identified include prejudicial and hostile working environment, inadequate mentoring and sponsorship, and the pressure to fit in. Banking/financial institutions should seek to have formal career paths and programmes that facilitate women's advancement into top management.

\section{References}

[1] Espi, G., Francis, D., Valodia, I. (2019). Gender inequality in the South African labour market: Insights from the Employment Equity Act data. Agenda, 33 (4), 44-61. doi: http://doi.org/10.1080/10130950.2019.1674675

[2] Kanjere, M. M., Ngwakwe, C. C. (2018). Progression of women to higher management positions in South African public sector: A differential effect of employment equity. Acta Universitatis Danubius Administratio, 9 (2), 47-59.

[3] Bosch, A., Barit, S. (2020). Gender pay transparency mechanisms: Future directions for South Africa. South African Journal of Science, 116 (3/4). doi: http://doi.org/10.17159/sajs.2020/6772/suppl

[4] Mkhethwa, M., Msweli, P. (2011). The impact of female business leaders on the performance of listed companies in South Africa. South African Journal of Economic and Management Sciences, 14 (1), 1-7. doi: http://doi.org/10.4102/sajems.v14i1.145

[5] Employment Equity Act 55. (1998). Pretoria. Government Printer. Available at: https://www.labourguide.co.za/downloadtop/135-eepdf

[6] Mayer, C.-H., Oosthuizen, R. M., Surtee, S. (2017). Emotional intelligence in South African women leaders in higher education. SA Journal of Industrial Psychology, 43. doi: http://doi.org/10.4102/sajip.v43.1405

[7] Statistics South Africa (StatsSA) (2020). Quarterly Labour Force Survey, Quarter 1:2020. Available at: http://www.statssa.gov. za/publications/P0211/P02111stQuarter2020.pdf

[8] Fajardo, C. (2017). Gender (dis)parity in South Africa. Available at: http://www.bain.com/publications/articles/gender-disparity-in-south-africa.aspx

[9] Statistics South Africa (StatsSA) (2019). Statistical release P0211: Quarterly Labour Force Survey Quarter 3:2019. Available at: https://www.statssa.gov.za/publications/P0211/P02113rdQuarter2019.pdf

[10] South African Bank Seta (2017). Banking Sector Skills Plan 2017/2018. Available at: https://www.bankseta.org.za/wp-content/ uploads/2017/12/BST1016_Banking_Sector_Skills_Plan.pdf

[11] Statistics South Africa (StatsSA) (2020). Gross domestic product, Second quarter 2020. Available at: http://www.statssa.gov. za/publications/P0441/P04412ndQuarter2020.pdf

[12] Smith, M., Ahmad, R. (2020). South African challengers take on big 4 within behavioral banking, low fees. Standard \& Poor's. Available at: https://www.spglobal.com/marketintelligence/en/news-insights/latest-news-headlines/south-african-challengers-take-on-big-4-with-behavioral-banking-low-fees-57157253

[13] Absa (2019). Absa Group Limited 2018 Integrated Report. Available at: https://www.absa.africa/content/dam/africa/absaafrica/ pdf/reports/2018/absa-group-2018-integrated-report.pdf

[14] FirstRand (2018). FirstRand Annual Financial Statements. Available at: https://www.firstrand.co.za/media/1666/firstrand-annual-financial-statements-30-june-2018.pdf

[15] Nedbank (2019). Transformation Report for year ended 31 December 2018. Available at: https://www.nedbank.co.za/content/dam/ nedbank/site-assets/AboutUs/Information\%20Hub/Integrated\%20Report/2018/2018\%20Transformation\%20Report(1).pdf

[16] Standard Bank (2019). Transformation report 2018. Available at: https://sustainability.standardbank.com/documents/pdf/ TransformationReport2018.pdf

[17] Rath, T. S., Mohanty, M., Pradhan, B. B. (2019). An alternative career progression model for Indian women bank managers: A labyrinth approach. Women's Studies International Forum, 73, 24-34. doi: http://doi.org/10.1016/j.wsif.2019.01.005

[18] Offermann, L. R., Thomas, K. R., Lanzo, L. A., Smith, L. N. (2020). Achieving leadership and success: A 28-year follow-up of college women leaders. The Leadership Quarterly, 31(4), 101345. doi: http://doi.org/10.1016/j.leaqua.2019.101345

[19] Rijal, S., Wasti, S. P. (2018). Factors influencing career progression of working women in health services: A case from Kathmandu Valley in Nepal. International Journal of Healthcare Management, 11 (3), 164-170. doi: http://doi.org/10.1080/ 20479700.2018 .1444952 
[20] Francescato, D., Lauriola, M., Giacomantonio, M., Mebane, M. E. (2020). Do personality traits and personal values predict career efficacy and career progression of successful political women? An exploratory study. Personality and Individual Differences, 160, 109918. doi: http://doi.org/10.1016/j.paid.2020.109918

[21] Doubell, M., Struwig, M. (2014). Factors influencing the career success of professional and business women in South Africa. South African Journal of Economic and Management Sciences, 17 (5), 531-543. doi: http://doi.org/10.4102/sajems.v17i5.514

[22] Pan, Y., Peng, X., Hu, T. Luo, J. (2017). Understanding what affects career progression using Linkedin and Twitter data. 2017 IEEE International Conference on Big Data, 2047-2055. doi: http://doi.org/10.1109/bigdata.2017.8258151

[23] Norman, L., Rankin-Wright, A. J., Allison, W. (2018). “It’s a Concrete Ceiling; It's Not Even Glass": Understanding Tenets of Organizational Culture That Supports the Progression of Women as Coaches and Coach Developers. Journal of Sport and Social Issues, 42 (5), 393-414. doi: http://doi.org/10.1177/0193723518790086

[24] Atkinson, J. (2011). Gendered organizations and women's career progression in the UK financial services sector. Journal of Social Welfare and Family Law, 33 (3), 243-254. doi: http://doi.org/10.1080/09649069.2011.626243

[25] Hill, L. H. Wheat, C. A. (2017). The influence of mentorship and role models on university women leaders' career paths to university presidency. The Qualitative Report, 22 (8), 2090-2111. doi: http://doi.org/10.46743/2160-3715/2017.2437

[26] Cirincione-Ulezi, N. (2020). Black Women and Barriers to Leadership in ABA. Behavior Analysis in Practice, 13 (4), $719-724$. doi: http://doi.org/10.1007/s40617-020-00444-9

[27] McLaughlin, H., Silvester, J., Bilimoria, D., Jané, S., Sealy, R., Peters, K. et. al. (2017). Women in power: Contributing factors that impact on women in organizations and politics; psychological research and best practice. Organizational Dynamics, 47 (3), 189-199. doi: http://doi.org/10.1016/j.orgdyn.2017.09.001

[28] Place, K. R., Vardeman-Winter, J. (2018). Where are the women? An examination of research on women and leadership in public relations. Public Relations Review, 44 (1), 165-173. doi: http://doi.org/10.1016/j.pubrev.2017.10.005

[29] Eagly, A. H., Heilman, M. E. (2016). Gender and leadership: Introduction to the special issue. The Leadership Quarterly, 27 (3), 349-353. doi: http://doi.org/10.1016/j.leaqua.2016.04.002

[30] Bastida Domínguez, M., Rivo-López, E., Villanueva-Villar, M. (2019). “The glass ceiling.” Organizational Dynamics, 48 (4), 100706. doi: http://doi.org/10.1016/j.orgdyn.2019.02.008

[31] Heilman, M. E. (2001). Description and prescription: How gender stereotypes prevent women's ascent up the organizational ladder. Journal of Social Issues, 57 (4), 657-674. doi: http://doi.org/10.1111/0022-4537.00234

[32] Paustian-Underdahl, S. C., Walker, L. S., Woehr, D. J. (2014). Gender and perceptions of leadership effectiveness: A meta-analysis of contextual moderators. Journal of Applied Psychology, 99 (6), 1129-1145. doi: http://doi.org/10.1037/a0036751

[33] Sink, A., Mastro, D., Dragojevic, M. (2017). Competent or Warm? A Stereotype Content Model Approach to Understanding Perceptions of Masculine and Effeminate Gay Television Characters. Journalism \& Mass Communication Quarterly, 95(3), 588-606. doi: http://doi.org/10.1177/1077699017706483

[34] Hoyt, C. L., Blascovich, J. (2007). Leadership efficacy and women leaders' responses to stereotype activation. Group Processes \& Intergroup Relations, 10 (4), 595-616. doi: http://doi.org/10.1177/1368430207084718

[35] Derks, B., Van Laar, C., Ellemers, N. (2016). The queen bee phenomenon: Why women leaders distance themselves from junior women. The Leadership Quarterly, 27 (3), 456-469. doi: http://doi.org/10.1016/j.leaqua.2015.12.007

[36] Aram, J. D., Salipante, P. F. (2003). Bridging Scholarship in Management: Epistemological Reflections. British Journal of Management, 14 (3), 189-205. doi: http://doi.org/10.1111/1467-8551.00374

[37] Saunders, M., Lewis, P. Thornhill, A. (2012). Research methods for business students. Edinburgh: Pearson Education Limited.

[38] Parker, P., Hewitt, B., Witheriff, J., Cooper, A. (2018). Frank and Fearless: Supporting Academic Career Progression for Women in an Australian Program. Administrative Sciences, 8 (1), 5. doi: http://doi.org/10.3390/admsci8010005

[39] Hoffmann, A., Musch, J. (2018). Prejudice against Women Leaders: Insights from an Indirect Questioning Approach. Sex Roles, 80 (11-12), 681-692. doi: http://doi.org/10.1007/s11199-018-0969-6

[40] Kark, R., Eagly, A. H. (2010). Gender and leadership: Negotiating the labyrinth. Handbook of gender research in psychology. New York: Springer, 443-468. doi: http://doi.org/10.1007/978-1-4419-1467-5_19

[41] Tal, D., Gordon, A. (2018). Women as Political Leaders: a Bibliometric Analysis of the Literature. Society, 5 5(3), $256-261$. doi: http://doi.org/10.1007/s12115-018-0248-8

[42] Hoyt, C. L., Murphy, S. E. (2016). Managing to clear the air: Stereotype threat, women, and leadership. The Leadership Quarterly, 27 (3), 387-399. doi: http://doi.org/10.1016/j.leaqua.2015.11.002

[43] Fiske, S. T., Cuddy, A. J. C., Glick, P., Xu, J. (2002). A model of (often mixed) stereotype content: Competence and warmth respectively follow from perceived status and competition. Journal of Personality and Social Psychology, 82 (6), 878-902. doi: http://doi.org/10.1037/0022-3514.82.6.878 
[44] Mavin, S. (2009). Navigating the labyrinth: senior women managing emotion. International Journal of Work Organisation and Emotion, 3 (1), 81-87. doi: http://doi.org/10.1504/ijwoe.2009.025401

[45] Ryan, M. K., Haslam, S. A., Morgenroth, T., Rink, F., Stoker, J., Peters, K. (2016). Getting on top of the glass cliff: Reviewing a decade of evidence, explanations, and impact. The Leadership Quarterly, 27 (3), 446-455. doi: http://doi.org/10.1016/ j.leaqua.2015.10.008

[46] Pradhan, R. K., Jena, L. K., Panigrahy, N. P. (2020). Do sustainability practices buffer the impact of self-efficacy on organisational citizenship behaviour? Journal of Indian Business Research, 12 (4), 509-528. doi: http://doi.org/10.1108/jibr-05-2019-0170

[47] Burkinshaw, P., White, K.; Antoniou, A., Cooper, G. Gatrell, C. (Eds.) (2019). Networking and gender equality in academic leadership. Women, Business and Leadership: gender and organisations. Cheltenham: Edward Elgar Publishing, 159-173. doi: http://doi.org/10.4337/9781786432711.00017

[48] Lammers, J., Gast, A. (2017). Stressing the Advantages of Female Leadership Can Place Women at a Disadvantage. Social Psychology, 48 (1), 28-39. doi: http://doi.org/10.1027/1864-9335/a000292

[49] Downey, L. A., Papageorgiou, V., Stough, C. (2006). Examining the relationship between leadership, emotional intelligence and intuition in senior female managers. Leadership \& Organization Development Journal, 27 (4), 250-264. doi: http:// doi.org/10.1108/01437730610666019

[50] Shah, V. H., Shah, P. P. (2019). How to Use Emotional Intelligence as a Career Catalyst - the X-Factor of Success for Trainees and Faculty in Gastroenterology and Hepatology. Gastroenterology, 157 (2), 289-292. doi: http://doi.org/10.1053/ j.gastro.2019.05.009

[51] Rubens, A., Schoenfeld, G. A., Schaffer, B. S., Leah, J. S. (2018). Self-awareness and leadership: Developing an individual strategic professional development plan in an MBA leadership course. The International Journal of Management Education, 16 (1), 1-13. doi: http://doi.org/10.1016/j.ijme.2017.11.001

[52] Xu, X., Yu, K. (2019). When Core Self-Evaluation Leads to Career Adaptability: Effects of Ethical Leadership and Implications for Citizenship Behavior. The Journal of Psychology, 153 (5), 463-477. doi: http://doi.org/10.1080/00223980. 2018.1564724

[53] Takawira, N. (2020). Mediation effect of perceived organisational and social support in the relationship between career adaptability and career satisfaction among professional women. Journal of Psychology in Africa, 30 (1), 23-29. doi: http://doi.org/ 10.1080/14330237.2020.1716550

[54] Udin, U., Handayani, S., Yuniawan, A., Rahardja, E. (2019). Leadership Styles and Communication Skills at Indonesian Higher Education: Patterns, Influences, and Applications for Organization. Organizations and Markets in Emerging Economies, 10 (1), 111-131. doi: http://doi.org/10.15388/omee.2019.10.00006

[55] McDowell Marinchak, C. L., Deluliis, D. Flinko, S. (2017). Finding Clarity: Professional Civility and the Art of Listening in Effective Business Communication. Listening, 52 (2), 66-84.

[56] Kanadl1, S. B., Torchia, M., Gabaldon, P. (2018). Increasing women's contribution on board decision making: The importance of chairperson leadership efficacy and board openness. European Management Journal, 36 (1), 91-104. doi: http:// doi.org/10.1016/j.emj.2017.03.006

[57] Cuddy, A. J. C., Fiske, S. T., Kwan, V. S. Y., Glick, P., Demoulin, S., Leyens, J.-P. et. al. (2009). Stereotype content model across cultures: Towards universal similarities and some differences. British Journal of Social Psychology, 48 (1), 1-33. doi: http:// doi.org/10.1348/014466608x314935

[58] Eckes, T. (2002). Paternalistic and envious gender stereotypes: Testing predictions from the stereotype content model. Sex Roles, 47 (3-4), 99-114. doi: http://doi.org/10.1023/a:1021020920715

[59] Dartey-Baah, K. Mekpor, B. (2017). Emotional intelligence: Does leadership style matter? Employees perception in ghana's banking sector. International Journal of Business, 22 (1), 41-54.

[60] Lopez-Zafra, E., Garcia-Retamero, R., Martos, M. P. B. (2012). The Relationship Between Transformational Leadership and Emotional Intelligence from a Gendered Approach. The Psychological Record, 62 (1), 97-114. doi: http://doi.org/10.1007/ bf03395790

[61] Darvin, L., Pegoraro, A., Berri, D. (2017). Are Men Better Leaders? An Investigation of Head Coaches' Gender and Individual Players' Performance in Amateur and Professional Women's Basketball. Sex Roles, 78 (7-8), 455-466. doi: http:// doi.org/10.1007/s11199-017-0815-2

[62] Jauhar, J., Lau, V. (2018). The 'glass ceiling' and women's career advancement to top management: The moderating effect of social support. Global Business and Management Research, 10 (1), 163-178.

[63] Napasri, T., Yukongdi, V. (2015). A study of Thai female executives: Perceived barriers to career advancement. Review of Integrative Business and Economics Research, 4 (3), 108-120 
[64] Woolley, L., Caza, A., Levy, L. (2011). Authentic leadership and follower development: Psychological capital, positive work climate, and gender. Journal of Leadership \& Organizational Studies, 18 (4), 438-448. doi: http://doi.org/10.1177/1548051810382013

[65] Hopkins, M. M., O’Neil, D. A. (2015). Authentic leadership: Application to women leaders. Frontiers in Psychology, 6. doi: http://doi.org/10.3389/fpsyg.2015.00959

[66] Glass, C., Cook, A. (2015). Leading at the top: Understanding women's challenges above the glass ceiling. The Leadership Quarterly, 27 (1), 51-63. doi: http://doi.org/10.1016/j.leaqua.2015.09.003

[67] Institute of Directors South Africa (IoDSA) (2016). King IV Report. Available at: https://apps.apple.com/za/app/king-iv-report/id1145317905

[68] Opstrup, N., Villadsen, A. R. (2014). The Right Mix? Gender Diversity in Top Management Teams and Financial Performance. Public Administration Review, 75 (2), 291-301. doi: http://doi.org/10.1111/puar.12310

[69] Palmer, A., Bosch, A. (2017). What makes representation of executive women in business happen? Equality, Diversity and Inclusion: An International Journal, 36 (4), 306-320. doi: http://doi.org/10.1108/edi-09-2016-0071

Received date 19.04.2021

Accepted date 25.05.2021

Published date 31.05.2021
(C) The Author(s) 2021

This is an open access article under the

Creative Commons CC BY license

How to cite. Kobus-Olawale, J., Schachtebeck, C., Dhanpat, N. (2021). Investigating career progression experiences of women into top management at a South African bank. EUREKA: Social and Humanities, 3, 28-40. doi: http://doi.org/10.21303/25045571.2021 .001778 